\title{
PEMBUATAN DAN PENGUJIAN TURBIN ULIR DUA SUDU
}

\author{
Slameto, Budi Suharto, Ervina Fitriana Bekti \\ Teknik Konversi Energi - Politeknik Negeri Bandung
}

\begin{abstract}
Abstrak
Turbin ulir mulai dikembangkan di Eropa pada akhir tahun 2007.Turbin Ulir ini cocok untuk daerah sungai-sungai yang ada di Indonesia karena pengoperasian turbin ulir dapat bekerja pada head yang rendah (Head<10). Selain turbin ulir, salah satu turbin yang dikembangkan yaitu turbin open flume. Turbin ulir yang dibuat jenis turbin ulir dua sudu. Dimensi turbin ulir disesuaikan dengan peralatan uji yang tersedia yaitu menggunakan uji turbin open flume. Ukuran dimensi turbin ulir diperoleh, diameter turbin 0,06 meter dan panjang turbin ulir 0,2 meter. Dari hasil pengujian diperoleh efisiensi turbin ulir dua sudu paling optimum sebesar 15,86\%, dengan daya yang dihasilakn sebesar 45,84 watt, pada tegangan 143,3 Volt dan arus 0,32 ampere.
\end{abstract}

Kata kunci : Mikrohidro, Turbin Ulir, open flume, efisiensi,

\section{PENDAHULUAN}

Listrik adalah sumber daya yang paling banyak digunakan karena memiliki banyak fungsi untuk menunjang kehidupan. Saat ini Indonesia masih bergantung kepada energi fosil sebagai bahan bakar pembangkit energi listrik.

Potensi energi terbarukan seperti energi mini/mikrohidro, energi biomassa, energi surya, energi angin, energi panas bumi, energi laut, dan energi nuklir di Indonesia cukup besar. Implementasi mikrohidro dilakukan dengan memanfaatkan potensi aliran air dengan head (ketinggian) dan debit tertentu yang dikonversi menjadi energi listrik melalui turbin dan generator.

Pada kenyataannnya, di Indonesia, ratarata menunjukkan bahwa potensi sumber daya airnya memiliki debit besar dan head yang rendah. Jadi, pengembangan turbin head rendah (low head) atau head sangat rendah (ultra low head) sangat cocok dikembangkan di Indonesia.

Jenis turbin dipilih jenis turbin ulir dua sudu, dengan pertimbangan cocok digunakan untuk head yang rendah [1]. Turbin air ini juga memiliki beberapa keunggulan antara lain ramah lingkungan, fish-freindly, mudah dalam konstruksi, instalasi dan perawatan, mudah dalam peroperasian dan biaya perawatan yang rendah [2]. Pada penelitian ini akan dilakukan perancangan dan pengujian turbin ulir dua sudu untuk mendapatkan perspektif yang lebih dalam terkait pengambangan turbin ulir dua sudu.

\section{METODOLOGIE}

Prinsip kerja turbin ulir didasarkan pada prinsip Archimedes screw, yaitu jenis ulir yang telah dikenal sejak zaman kuno dan telah digunakan sebagai pompa untuk pengairan pada Taman Bergantung di Babylonia. Seiring dengan krisis energi yang terjadi di dunia serta terbatasnya potensi sumber energi air yang memiliki head tinggi, maka jika pompa ulir berputar terbalik dan membiarkan air mengendalikan pompa kemudian di atas pompa tersebut dipasang sebuah generator maka listrik akan dapat dihasilkan sepanjang generator tersebut tidak terkena air atau basah. Jadi pada prinsipnya turbin ulir merupakan pembalikan dari fungsi pompa ulir itu sendiri.

\section{Tahapan rancangan}

Dalam melakukan rancang bangun, tahapan yang dilakukan sebagai berikut :

1. Perhitungan Perancangan

2. Pembuatan peralatan simulasi pembangkit listrik

3. Pengujian peralatan

Pengujian yang akan dilakukan adalah pengujian kinerja peralatan, metode yang dipilh yaitu dengan variasi beban untuk bukaan katup tertentu.

\section{Perancangan Turbin Ulir}

Turbin ulir merubah energi potensial air menjadi energi mekanik poros, selanjutnya energi mekanik poros ini diubah menjadi energi listrik melalui generator yang dikopel pada turbin ulir [3]. 


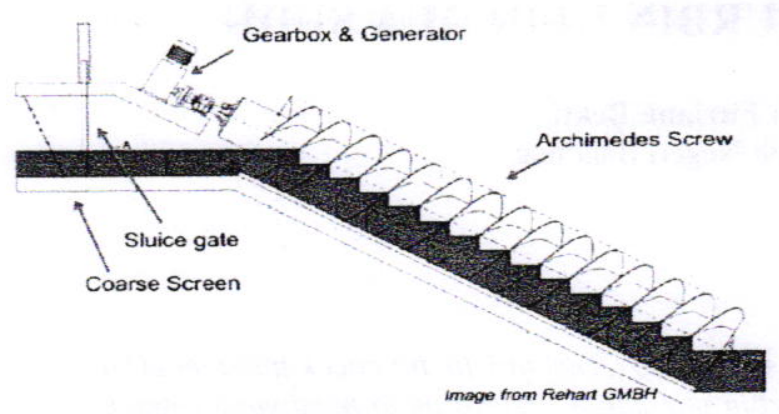

Gambar.1 Turbin Ulir

\section{Daya Hidrolis}

Daya hidrolis yang tersedia dapat dirumuskan dari persamaan berikut:

$$
P=\rho \cdot g \cdot H \cdot Q
$$

Dimana :

$\mathrm{P}=$ Daya Turbin $(\mathrm{W})$

$\mathrm{Q}=$ kapasitas air $\left(\mathrm{m}^{3} /\right.$ detik $)$

$\rho=$ kerapatan air $\left(\mathrm{kg} / \mathrm{m}^{3}\right)$

$g=$ gaya gravitasi $\left(\mathrm{m} / \mathrm{s}^{2}\right)$

$H=$ tinggi air jatuh (m)

\section{Daya Generator}

Daya generator yang dihasilkan dihitung berdasarkan persamaan berikut ;

$$
P=V \cdot I \cdot \cos \theta
$$

Dimana:

$$
\begin{aligned}
& \mathrm{P}=\text { Daya Generator (W) } \\
& \mathrm{I}=\text { Arus (Ampere) } \\
& \cos \theta=\text { faktor daya }
\end{aligned}
$$

\section{Efisiensi}

Efisiensi system diperoleh berdasarkan rumus

$$
\eta=\frac{P \text { output }}{P_{\text {input }}} \times 100
$$

Dimana :

P output $=$ Daya Generator $(\mathrm{W})$

$\mathrm{P}$ input $=$ Daya Hidrolis $(\mathrm{W})$

$\eta=$ Effisiensi $(\%)$

\section{HASIL DAN PEMBAHASAN}

\section{Hasi Rancangan}

Hasil rancangan turbin ulir sebagai berikut :

Dari data awal yang tersedia yaitu head $5 \mathrm{~m}$, diperoleh data turbin awal sebagai berikut

- Head efektif $(\mathrm{H})$

: 5 meter

- Sudut Ulir

$: 45^{\circ}$

- Sudut awal turbin

$: 90^{\circ}$

- Kecepatan Aliran (V)

: $2,899 \mathrm{~m} / \mathrm{s}$

- Debit aliran (Q)

$: 2,6$ liter/s

- Panjang turbin

: $0,2 \mathrm{~m}$

- Diameter poros turbin

$: 0,025 \mathrm{~m}$

- Panjang poros turbin

: $0,23 \mathrm{~m}$

- Tinggi sudu turbin

: $0,04 \mathrm{~m}$

- Jumlah sudu turbin

$: 2$ buah

- Diameter total turbin (D)

: $0,06 \mathrm{~m}$

- Putaran turbin (n)

- Banyak cycle

: $2700 \mathrm{rpm}$

$: 4$ cycle

\section{Hasil Pengujian}

Pengujian sistem menggunakan turbin ulir dua sudu dilakukan di Laboratorium Teknik Konversi Energi. Parameter yang diambil saat pengujian adalah kecepatan putaran turbin, tegangan generator, arus keluaran generator dan $\cos \theta$. Pengujian dilakukan dengan beban bervariasi bukaan katup tetap.

Tabel 1. Data hasil pengujian

\begin{tabular}{|c|c|c|c|c|c|}
\hline $\begin{array}{c}\text { Beban } \\
\text { [Watt] }\end{array}$ & $\begin{array}{c}\text { Putaran } \\
{[\mathrm{rpm}]}\end{array}$ & $\begin{array}{c}\text { Tegangan } \\
\text { [Volt] }\end{array}$ & $\begin{array}{c}\text { Arus } \\
\text { [Ampere] }\end{array}$ & $\begin{array}{c}\text { cos } \\
\text { phi }\end{array}$ & Debit $\left[\mathrm{m}^{3} / \mathrm{s}\right]$ \\
\hline 0 & 2520 & 163,4 & 0,00 & 0,000 & 0,0061 \\
\hline 15 & 2467 & 156,4 & 0,06 & 0,960 & 0,0059 \\
\hline 30 & 2375 & 153,1 & 0,11 & 0,996 & 0,0059 \\
\hline 45 & 2301 & 149,8 & 0,16 & 0,976 & 0,0059 \\
\hline 60 & 2205 & 145,2 & 0,21 & 0,990 & 0,0059 \\
\hline 75 & 2121 & 145,0 & 0,26 & 0,999 & 0,0059 \\
\hline 90 & 2030 & 143,3 & 0,32 & 1,000 & 0,0059 \\
\hline 105 & 1911 & 105,3 & 0,33 & 0,999 & 0,0059 \\
\hline 120 & 1814 & 105,2 & 0,35 & 1,000 & 0,0059 \\
\hline 135 & 1764 & 104,6 & 0,37 & 1,000 & 0,0059 \\
\hline 150 & 1712 & 102,3 & 0,41 & 1,000 & 0,0059 \\
\hline
\end{tabular}




\section{Pembahasan}

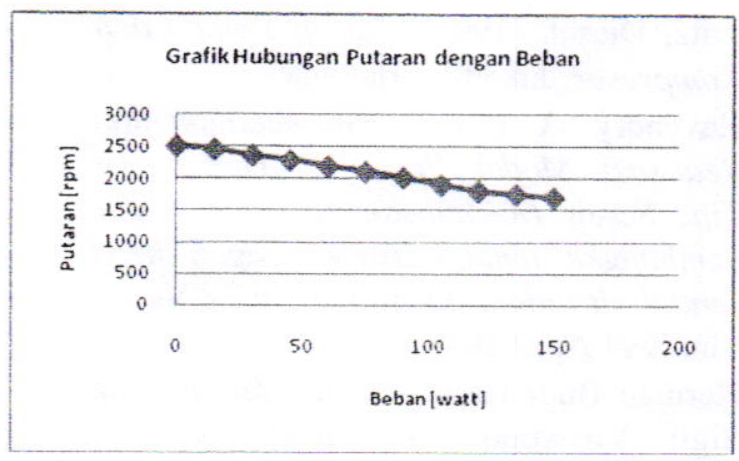

Gambar 2.Hubungan Putaran terhadap Beban

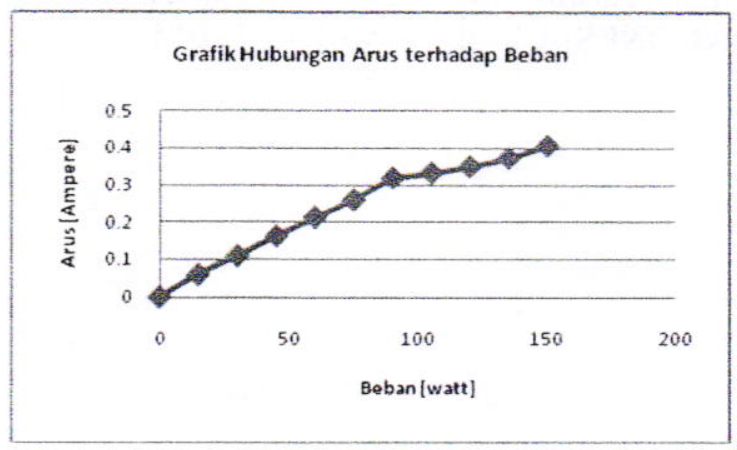

Gambar 3.Hubungan Arus terhadap Beban

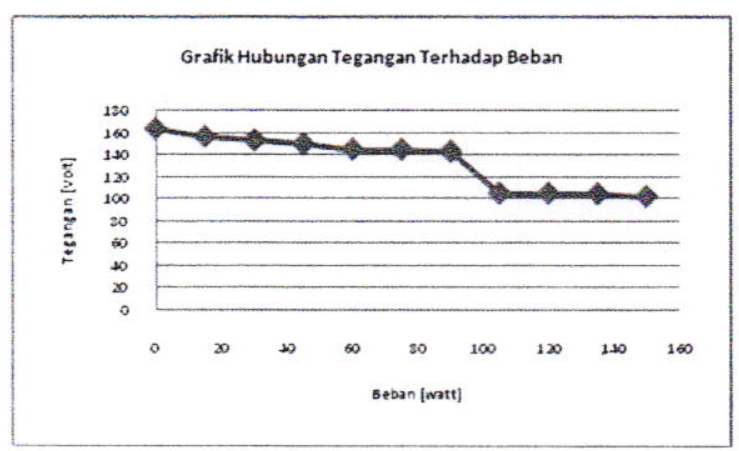

Gambar 4.Hubungan Tegangan terhadap Beban

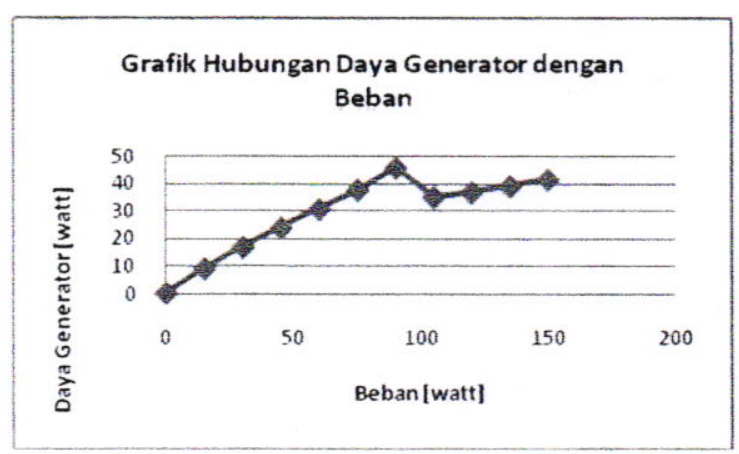

Gambar 5.Hubungan Daya keluaran terhadap Beban
Dari grafik, putaran turbin semakin turun dengan semakin naiknya beban. Untuk hubungan arus terhadap beban terlihat semakin tinggi beban, arus yang dihasilkan semakin tinggi. Sementara sebaliknya pada hubungan tegangan terhadap beban terlihat semakin tinggi beban, tegangan yang dihasilkan semakin menurun. Sejalan dengan pengamatan arus dan tegangan erhadap beban maka grafik daya juga menunjukan hubungan semakin tinggi pembebanan, daya output keluaran turbin semakin tinggi.

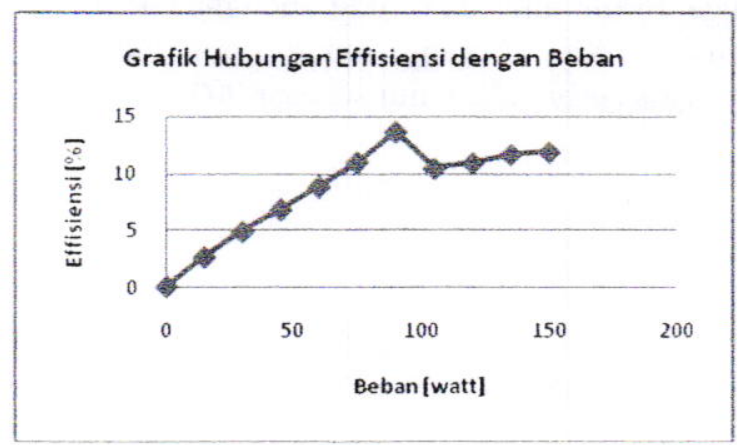

Gambar 6.Hubungan efisiensi terhadap beban

Efisiensi semakin meningkat ketika pembebanan meningkat, sampai mencapai efisiensi optimum dan efisiensi akan turun ketika pembebanan diperbesar efisiensi optimum sebesar $15,86 \%$ pada putaran 2030 rpm, tegangan 143,3 V, Daya yang dihasilkan sebesar 45,84 watt.

\section{KESIMPULAN}

Kesimpulan dari pembuatan dan pengujian turbin ulir dua sudu adalah sebagai berikut :

1. Hasil rancangan dan pembuatan turbin ulir dua sudu diperoleh dimensi turbin yaitu:

- Diameter : 0,06 meter

- Panjang Turbin

: 0,2 meter

- Pitch

: 0,027 meter

- Tinggi sudu turbin : 0,04 meter

2. Hasil pengujian turbin ulir dua sudu open flume pada debit $0,0059 \mathrm{~m}^{3} / \mathrm{s}$ dan head 5 meter menghasilkan efisiensi tertinggi sebesar 15,86 \% dengan daya aktual sebesar $45,84 \mathrm{~W}$.

3. Tegangan tertinggi yang dihasilkan 156,4 Volt , arus 0,06 ampere dan putaran 2467rpm. 
4. Hasil analisis pada penambahan beban maka putaran dan tegangan turbin akan semakin menurun, sedangkan arus semakin naik. Daya output akan semakin naik seiring bertambahnya beban.

5. Apabila turbin dibebani pada beban melebihi kapasitas turbin 100 watt, maka tegangan akan jatuh menurun.

Hasil analisis berdasarkan hasil pengujian dan perhitungan didapat hasil yang masih jauh dari perencanaan. Hal ini diakibatkan ketersediaan debit yang kecil, sehingga turbin ulir dua sudu menghasilkan effisiensi $15,86 \%$ yang cukup jauh dari karakteristik turbin ulir yaitu sebesar $90 \%$.

\section{DAFTAR PUSTAKA}

[1] Fritz, Diesel, (1996). Turbin Pompa dan Kompresor. Jakarta: Erlangga

[2] Havendry, A. (2009). Perancangan dan Realisasi Model Prototipe Turbin Air Tipe Screw (Archimedes Turbine) untuk pembangkit tenaga listrik dengan head rendah di Indonesia. Jurnal No.31 Vol. 2 Thn XVI April 2009.

[3] Herman Budi Harja, Halim Abdurrahim, Sigit Yoewono dan Hendi Riyanto, (2014) Penentuan Dimensi Sudu Turbin Dan Sudut Kemiringan Poros Turbin Pada Turbin Ulir Archimedes, METAL INDONESIA VOL.36 No.1 Juni 2014 